\title{
LINGUISTICS AS MATERIALS IN TEFL AND TESOL
}

\author{
By Prof.Seno H Putra, Drs.,M.Pd.,Ph.D \\ Linguistic Professor of the Islamic University of Riau, Pekanbaru, Indonesia
}

\section{A.Concept of Linguistics}

What is Linguistics? If this question rises, of course, somebody will get confuse, and different answers also exist. Why is it so? Somebody only thinks it over that "Linguistics" only focuses on "Speaking and Writing", but that is actually not only concerned with two skills enough, but that is also related to the broad scope, including its branches if it is explained one by one scientifically. Therefore, according to Seno (2001) Linguistics is a science that we study about Language and its branches specific and universal, as well as verbal and nonverbal ones. It is, moreover, similar to other fields of science. Detailly, according to its task and function has many uses in daily life of human in the World, or in short, no Linguistics no activities of Human and Science and Technology formally and non-formally in their life.In other words, everybody in the World uses Linguistics in their life both verbal and non-verbal.

\section{B.Language Phenomena}

Many phenomena (problems) that can be found by us in Human's life in using Language (Linguistics) verbally whether formal or non formal. As stated by Seno H Putra (2000), Linguistics is a science that We study about Human's Language specific and universal, as well as verbal and non-verbal, and it also encompasses some branches, such as Phonology, Morphology, Syntax, Structure, Semantics, Sociolinguistics, Psycholinguitics, Discourse Analysis, Pragmatics, Linguistics in Mathematics, Linguistics in Arts, Linguistics in Science and 
Technology, Culture in Linguistics, etc., (Senoputra,2004), these that can be materials of study deeply by those who are intersted in.

\section{C.Human Speeches}

Why are human Speeches focused on Linguistics? This question to be interesting to those who involve in Linguistic Studies. To answer this, there are some scientific reasons and argumentations that I offer to the readers. First, according to (The God-Allah) in Al-Qur'an, Sentence "Albaqarah" in (Seno H Putra, 2004-2008) stated that Language firstly exists in the World starting from the Adam Prophet through out speeches of Human; second, all normal people in the World use speeches rather than written one starting from a baby until old ones; third, all activities of Human in family, Society, Nation, and global whether non formal or formal athmospher also use Language in spoken; and fourth, Linguistics involves all activities of Human in the World, and even hereafter.

\section{Why Linguistics needs Research?}

Linguistics is also similar to other fields of Science which can be researched, and the results of research can also be contributed not only for Society, but also for Academics (Chrystal, 1975;Chomsky,1969; and Seno Putra, 2000). Moreover, Linguistics needs to be researched, since Linguistics and its branches are always used and applied by human both normal or unnormal in their own daily life activities. Besides that, the results of Linguistic Research found by the Linguists called as (Concepts/Theory) which can also be contributed for Teaching Language at each level of Schools, Colleges, and Universities, in this case, for example, Linguistics in English, where the results that can be applied and taught for TEFL or TESOL depends on the Language used by the Community (Seno Putra,2011; William, 1992).

As I said above, many phenomena (problems) that can be found in Linguistics and its branches used and applied by people in reality, which can be materials to be researched scientifically, for examples, Pronunciation, Phonology, 
Morphology, Syntax, Semantics, Psycholinguistics, Sociolinguistics, Discourse, Pragmatics, Linguistics in Mathematics, Linguistics in Culture, Applied Linguistics that can be splited to be sub problems, such as (Structure, Vocabulary, Speaking, Reading, Listening, and Writing), etc., these can concepts/theories for Academics.

\section{E. Linguistic Theory Relation with TEFL or TESOL}

It is impossible for Teaching and Learning Process of Language without any theories of Linguitics used by Teachers, Lecturers, Instructors then called as Mediators and Practicians. From the theories of Linguistics found by Linguists in their own studies can also be contributed as documents of Linguistics, Linguistic Institutions, TEFL, TESOL, as well as for Teaching and Learning Language, namely English, in this case, used, applied, and taught by the Mediators to the Students of each level of Education, besides, the students can also learn the theories of Linguistics as sources or references of their own learning to undesrtand, comprehend, and master them step by step depend on individual or a group of learning whether to be quick mastery or be slow mastery of Language learning depends on him/her (Seno Putra, 2010).

\section{F. Mediators in Linguistics and Devices of Teaching}

As I mentioned above, Mediators besides mastery of Linguistic Theories, they also hopely have and master other devices which can be used by them in Teaching and Learning Process of Language, such as Curriculum, Syllabus, Materials, Techniques, Methods, Strategies, Models, Media, Technology, etc. These devices are as instruments used and applied by the Mediators in the Teaching and Learning Process of Language to the Students whether in TEFL or TESOL (Seno Putra, 2006). 


\section{G. Curriculum}

What is Curriculum? Many Definitions and concepts/Theories explained by the Experts. Among them, namely, Oxford Dictionary (1987) states that Curriculum is a course of study in a School, College, etc. In this case, it means that the curriculum based on National or local, especially the subjects matters

profesionally and specifically which must be mastered by the Meadiators to explain the materials to the Students.

\section{H. Syllabus}

Syllabus is outline or summary of a course or studies, program of School studies. Syllabus in my opinion, is a detaled decription of Teaching materials used by the Lecturers in the Teaching and Learning process to the students for one semester in College or Universities.

\section{I.Model}

Model is the design to be copied, or Person or thing to be copied (Oxford, 1987:544). In my opinion, model is also main source for Teaching and Learning process in Education, for example, model indicates Human, like Teacher, Instructor, Lecturer, etc., called as (Mediator and Practician), in which they can be imitated or copied by the followers (Students), especially in a good character, behaviour, action, style, etc. In addition to this, model refers to thing is instruments used by Mediator in the Teaching and Learning process, like real things.

\section{J.Strategy}

Strategy is skill in managing any affair (Oxford,1987). In this case, I mean that it is a kind skill of Human, for examples, Teacher, Instructor, Lecturer 
(mediator) to manage classroom which consists of various character, behaviour, action, style, culture of Students to improve Education.

\section{K.Technique}

Technique is a method of doing something expertly (Oxford, 1987). In my opinion, in thise case, it means that professionalization, skill, comprehension, and mastery of individual, in this case, namely; a Teacher, Lecturer, Instructor, Mediator to transfer his/her knowledge to students as objects.

\section{L.Method}

Method is way of doing something of Teaching, System, Orderlines (oxford, 1987). In this case, it means that a Teacher, Lecturer, Instructor, or (Mediator) before the Teaching and Learning Process of Materials to the Students, they must have vision, mission, and programs, as well as the aims to reach the achievement of Teaching and Education.

\section{Media}

Media is mass communication, such as electronics or print, etc.This means instruments, such as Picturs, TV, Radio, Tape Recorder, CD/VCD, On Focus, Tansparancy, Computer, Laptop, etc., used by the Mediators to support their own Teaching that can be comprehended by the Students.

\section{N.TEACHING AND LEARNING PROCESS OF TEFL AND TESOL}

In the Education, especially in the Teaching and Learning Process of TEFL and TESOL, the process comes from Input called as Students, in which these 
Students, later on, that can be put to the Mechine called as Mechine Process. In here, the Students must be proceeded by the Mediators as the main Sources and others called as various materials of Teaching and Learning Process. In various Materials, the Mediators must also master Science, Skills, Pedagogy and Education that can be provided by other above devices to achieve their own Teaching and Education to the Students. Moreover, in the Teaching and Learning Process of various Materials, namely; Pronunciation, Structure, other Skills of Language, such as Speaking, Reading, Writing, and Listening, these are as the basic materials must be mastered by the Mediators which can be transfered to the students. Besides this, how do they teach? of course, hopely by applying Realia and Lifely Teaching. Where? This athmospher can be taught and applied in formal and non formal Education (Seno Putra, 2001-2008).

\section{O.Output of TEFL or TESOL}

The Last Procedure and Process of Teaching and Learning of TEFL or TESOL is the Output which refers to Achievement and Mastery of Materials taught by the Mediators or Practicians through out the Evaluation to the Students. The output and Evaluation are needed by the Mediators in order to know whether the Achivement and Mastery of both Teachers and Students are success $r$ not. In this case, the Mediators must use instruments of test to measure the ability or the competence of Students during their Learning or Lecturing. In Short, Linguistics is the theory of TEFL or TESOL used and mastered by the Mediators, then this must also provided by other devices as mentioned above to support the achievement and mastery of Teaching, Learning, and Education.

\section{References}

Byrne, Donn.1992. Technigues for Classroom Interaction. London: Longman. 
Hornby, AS..1987. Oxford Advanced Learner's Dictionary of Current English.GreatBritain. Oxford University Press.

Putra, Seno. 2006. Introduction to General Linguistics. Pekanbaru: Unri Press.

Putra, Seno. 2008. Mutu Pendidikan dan Hubungannya di Masyarakat: Makalah Nasional: Pekanbaru.

Putra, Seno.2005. English Semantics.Pekanbaru: Lembaga Reset Riau.

Putra, Seno.2007. Psycholinguistics. Pekanbaru: Lembaga Reset Riau.

Putra, Seno. 2001. Linguistics in TEFL. Jurnal Perpektif. Pekanbaru: PKIP UIR

Putra, Seno.2008. Al-Qur'an: Linguistics and Culture Involve in Science and Technology.Orasi Pengukuhan Guru Besar. Pekanbaru: UIR.

Putra, Seno. 2004. Linguistik Hubungannya dengan Ilmu Pengetahuan dan Teknologi. Orasi Dies Natalis, UIR. Pekanbaru: UIR dan Lembaga Reset Riau.

Putra, Seno. 2006. Penomena Pendidikan. Pekanbaru: Unri Press.

Grab, William and Kaplan, Robert.1992. Introduction to Applied Linguistics. Massachusetts: Addition-Wesley Publishing.

Van Els.Theo.1989. Applied Linguistics and the Learning and Teaching of Foreign Language. New York: Edward Arnold. 
